\title{
Education in uncertainty: Academic life as Indigenous health scholars during COVID-19
}

\author{
Tracey Galloway ${ }^{1}$. Andrea Bowra ${ }^{2}$. Tenzin Butsang ${ }^{2}$. \\ Angela Mashford-Pringle ${ }^{2}$ D
}

Accepted: 18 November 2020 / Published online: 30 November 2020

(c) UNESCO Institute for Lifelong Learning and Springer Nature B.V. 2020

\begin{abstract}
As the COVID-19 crisis continues to develop, communities around the world find themselves living in new and uncertain times. School and university closures are significantly disrupting the lives of students, educators and researchers alike. With the sudden shift to online learning platforms, the limitations on research projects and the lack of standardised policies and procedures, many concerns arise surrounding the unequal impacts of this crisis. This article brings together diverse perspectives on the effects of COVID-19 on post-secondary life for students and scholars engaged in the field of Indigenous health research. The authors reflect on how this time has impacted them as a graduating student, incoming PhD student, junior faculty member and mid-career faculty member respectively. Their experiences of teaching and learning at a large, research-intensive university in Toronto, Canada have been profoundly transformed, and will continue to change the way they work, research and interact at the graduate level. Working with Indigenous communities and organisations requires relationship building, collaboration and ceremony. In these unprecedented times, scholars cannot simply continue "business as usual". They must adapt everything, including how they teach, learn and work with Indigenous peoples, who are particularly vulnerable to this pandemic. Reflecting on the impacts that have already occurred and those that are still likely to come, the authors discuss what changes may need to be made in academia to support diverse actors within their scholarly community. They suggest changes to their scholarship with Indigenous communities in Canada to help them continue to work in a respectful, reciprocal and culturally appropriate way.
\end{abstract}

Keywords COVID-19 - post-secondary education · Indigenous health · Indigenous research $\cdot$ student experience $\cdot$ faculty members' experience

Angela Mashford-Pringle

angela.mashford.pringle@utoronto.ca

Extended author information available on the last page of the article 


\section{Résumé}

L'éducation dans des temps incertains : la vie universitaire pour les chercheurs dans le domaine de la santé des autochtones à l'heure de la COVID-19 - La crise de la COVID-19, qui continue de prendre de l'ampleur, plonge des communautés du monde entier dans des périodes inédites et incertaines. Les fermetures d'écoles et d'universités perturbent considérablement la vie des étudiants au même titre que celle des éducateurs et des chercheurs. Le brusque passage aux plateformes d'apprentissage en ligne, les restrictions imposées aux projets de recherche et l'absence de politiques et de procédés standardisés ont fait apparaître des préoccupations concernant l'impact hétérogène de la crise en cours. Cet article réunit différents points de vue sur les effets qu'a la COVID-19 sur la vie des étudiants de troisième cycle et des chercheurs dans le domaine de la recherche sur la santé des autochtones. Les auteures se penchent sur la façon dont cette période a impacté leur existence respectivement en tant qu'étudiante en fin de deuxième cycle, future doctorante et membres du corps professoral en début et en milieu de carrière ; une période qui a profondément marqué leur expérience de l'enseignement et de l'apprentissage dans une université centrée sur la recherche dans la ville canadienne de Toronto, et qui continuera à transformer leur façon de travailler, de faire de la recherche et d'interagir au niveau de l'enseignement supérieur. Travailler avec des communautés et organisations autochtones exige de construire des relations et de collaborer avec elles, et de respecter leurs usages. En cette période sans précédent, les universitaires ne peuvent pas faire comme si de rien n'était. Ils doivent tout adapter, y compris leur façon d'enseigner, d'apprendre et de travailler avec les peuples autochtones, particulièrement vulnérables face à cette pandémie. Dans une réflexion sur les conséquences qui se sont déjà fait sentir et sur celles probablement à venir, les auteures se penchent sur les changements susceptibles de devenir indispensables dans la sphère universitaire pour soutenir différents acteurs de leur communauté scientifique. Elles proposent des changements à leur travail avec les communautés autochtones au Canada pour les aider à continuer à opérer dans le respect et la réciprocité, et de façon adaptée sur le plan culturel.

\section{Introduction}

Historical and ongoing colonial violence against Indigenous communities in the settler state of Canada has left many communities disproportionately unprepared for the COVID-19 global pandemic. The Indian Act, instituted in 1876 (PC 1985 [1876]), allowed the federal government to systematically oppress First Nations, Métis and Inuit people ${ }^{1}$ by withholding basic autonomies such as the right to self-identify as Indigenous (Smylie and Firestone 2015). As a direct result, many

\footnotetext{
1 Canada's Indigenous population consists of three main groups. The term First Nations refers to the original people of this land (e.g. Algonquin, Cree, Dakota, Mohawk, Ojibwe and many more) who are neither Métis or Inuit. Métis are those who self-identify and are from a historic Métis Nation and accepted by that nation. Inuit are circumpolar peoples who have a distinct language, culture and traditions and live primarily in Inuit Nunangat (and parts of Alaska).
} 
Indigenous and Métis people are consistently excluded from census and health data collections (Freemantle et al. 2015), calling into question the accuracy of data on the impact of COVID-19 on Indigenous peoples in Canada. Under the same Act until 1985, Indigenous women who married non-Indigenous men lost their Indian status. Despite subsequent changes, past legislation continues to have a significant impact on subsequent generations. Loss of status has prevented thousands of Indigenous people from receiving medical coverage and other valuable social benefits (Reading and Wien 2009), an issue that becomes critically important during a pandemic.

While the impacts of this pandemic vary due to the diverse nature of Indigenous communities, many face issues such as poor housing and lack of clean water which make it difficult to adhere to public health recommendations such as self-isolation and social distancing (Thompson et al. 2020). As it stands, the Indian Act designates the Crown ${ }^{2}$ as trustee of reserve lands. The existing channels for property ownership are a significant deterrent to individuals and communities on reserves seeking to legally own the land (Aragón and Kessler 2020). They are unable to obtain mortgages or sizeable loans from the banks, as the property cannot be seized. These systemic barriers make it difficult for individuals to make investments in their housing or provide healthy living conditions for their families. These issues of inequity, along with many others, have long been and continue to be raised by many Indigenous community members, activists and scholars across the country. While the COVID19 pandemic is undoubtedly a global health crisis, its impacts reach far beyond the health sector (Humphreys 2020). Indigenous scholarship in particular is becoming increasingly recognised as a tool for advocacy and social change (Allen et al. 2020; Richmond and Cook 2016). As governments around the world heed advice from local and international public health experts, making the difficult yet necessary decision to close college and university campuses (Canadian Press 2020), these closures have significantly disrupted the learning and research of those engaged in the field of Indigenous health research.

While reports and preliminary analyses outlining the impacts of COVID-19 on post-secondary education continue to emerge, the majority of existing literature focuses on two areas: (1) medical education (Almarzooq et al. 2020; Nic Dhonncha and Murphy 2020; Rose 2020a) and (2) the mental health impacts of school closures on students (Lee 2020; Nicola et al. 2020; Sahu 2020; Viner et al. 2020). There is a significant absence of material pertaining to the specific implications for students and scholars in the field of Indigenous health research.

The objective of this article is therefore to bring together diverse perspectives on the effects of COVID-19 on post-secondary life in the field of Indigenous health, and to discuss how the virus has impacted scholars' experiences of Indigenous health scholarship. As an incoming $\mathrm{PhD}$ student, a graduating student, a junior faculty member and a mid-career researcher, we reflect on the varying impacts that online learning platforms, research limitations and lack of standardised procedures and protocols have had on our academic experiences. While these experiences at a large

\footnotetext{
${ }^{2}$ Canada is a constitutional monarchy, and the Crown refers to its current sovereign, Elizabeth II, Queen of the United Kingdom and 15 other Commonwealth realms.
} 
research-focused university in Toronto, Canada vary based on roles and responsibilities, certain aspects of working in Indigenous health at the graduate and professional level share commonalities.

As is traditional in Indigenous literature, we situate ourselves in order to provide the reader with a better understanding of our perspectives in this article. Andrea Bowra is an incoming PhD student from white settler ancestry currently working as a Research Coordinator in Indigenous health. Tenzin Butsan is a first-generation Masters student graduating as part of the inaugural cohort of the Master of Public Health in Indigenous Health programme. ${ }^{3}$ Tracey Galloway is an established scholar with 10 years of experience using settler decolonising perspective ${ }^{4}$ to identify structural and policy barriers to Canada's northern Indigenous people's health. Angela Mashford-Pringle is an Algonquin early-career professor working with Indigenous people to improve our collective health and well-being through reclaiming Anishinawbe culture with and on the land.

\section{Perspectives from Andrea Bowra, an incoming PhD student}

A primary responsibility of academic institutions is to nurture the future leaders who will foster society's health and well-being. This responsibility is exemplified in the duty we, as academics, owe to students - a duty which is compounded by the culpability of institutions of higher learning in harms perpetrated on Indigenous peoples under the guise of education and research.

Undergraduate and graduate students who enter academic institutions are seeking knowledge and authority to address the challenges they face in their own lives. It is essential that their experiences are understood so that they can be supported in their learning journeys. This support can take many different forms, including in-person supervision and discussion, classroom interaction, land-based learning ${ }^{5}$ with Elders, Knowledge Keepers and community members, and connections to other networks (Wildcat et al. 2014).

During the current pandemic, incoming students face multiple uncertainties, which are overlaid with the existing pressures on graduate and undergraduate education. Broadly, students describe these COVID-induced uncertainties as a general lack of clarity on how classes, research and teaching assistantships will function in the coming semesters. In non-pandemic times, students review and re-review

\footnotetext{
${ }^{3}$ For more information about the Master of Public Health (MPH): Indigenous Health, visit https://www. dlsph.utoronto.ca/program/mph-indigenous-health// [accessed 6 November 2020].

4 Settler decolonising perspective refers to the use of a theoretical framework that "explicitly engages with imperialism and colonialism at multiple levels" (Fortier 2017, p. 20) and that critically engages with the power relations whereby Indigenous ways of knowing have been and continue to be marginalised and delegitimised within Western-informed research theory and practice (Fortier 2017; Attas 2019).

5 The term land-based (e.g. in land-based learning) refers to the learning that takes place on and with the land in an Indigenous way. Though practices vary to match the diversity of Indigenous peoples, in many Indigenous ways of knowing, land is seen as the basis of all life, and is therefore the foundation for all cultural and traditional teachings (Bowra et al. 2020).
} 
university and college communications to understand exactly what steps are required to meet expectations. At this unprecedented time, as post-secondary institutions rapidly experiment with new modes of student support and course delivery, this process is much less straightforward. It is particularly confusing for incoming students, who have no context from which to assess what is "normal" and makes the process of getting started incredibly stressful for students. The lack of in-person support means that many students experience delayed and often limited information on their progress through admissions and course selection.

Some post-secondary institutions have announced plans to employ a blended model of online and in-person classes from September. ${ }^{6}$ This has left many students uncertain as to what their courses and campus-related activities will look like in the coming academic year. Though it is possible for most course content to be transferred to online formats, many peripheral benefits of in-person interaction will be lost. In-person classes offer space for relationship building with other students and instructors. Weekly interactions with peers allow students to form meaningful support networks with others who face similar academic situations. These networks are integral to helping students meet and overcome the many challenges with which post-secondary education presents them. Peers provide mental and emotional support in ways that other support networks may not, as they can relate to similar situations and offer practical, experience-based solutions.

In-person classes also offer important opportunities for students to build relationships with their professors. As many of us who interact with academic institutions know, competing priorities and high expectations create demanding work environments, busy schedules and inundated inboxes. The short times before and after classes are spaces where students can connect with their professors to ask questions and discuss course material. Potentially even more important than the discussion of academic content itself, however, is the space that these interactions allow for building a meaningful relationship with professors. Professors are experts in their fields and are therefore an invaluable resource for their students. As students look to move forward with their learning, research and careers, professors are important sources of information on relevant resources, connections to other scholars and potential career opportunities.

Beyond course schedules and formats, many graduate students face further uncertainties surrounding their own research projects and the projects that they are involved in through research and graduate assistant positions. Many research projects that involve in-person interactions, whether on-site at a laboratory or in the community interacting with the public, have been put on hold indefinitely. While these are necessary precautions, many students are losing critical opportunities to practise and develop the research skills they need to move forward with their education and careers. Moreover, students are also losing valuable chances to learn from experienced researchers and mentors, interactions which are vital for developing scholars.

\footnotetext{
${ }^{6}$ This article was drafted in July 2020.
} 
Other significant academic experiences that have been and continue to be cancelled or postponed during these times are academic conferences. As well as offering valuable opportunities for students to develop their oral presentation skills, conferences allow students to learn from and network with leading academics outside of their institutions. They offer unique spaces where scholars and community members from across the country and around the world gather to discuss emerging research. Conference presentations are an essential component of an academic CV and are therefore indispensable for developing scholars. Presentations made at conferences demonstrate to admissions and awards committees a scholar's ability and commitment to mobilising research knowledge within the academic community, a skill which is highly valued across disciplines.

\section{Perspectives from Tenzin Butsang, a graduating Masters student}

Students reaching the end of a period of study face new pressures associated with graduation and the transition to employment. Strategies developed to support them during their studies have been suddenly and profoundly altered by the COVID-19 pandemic, in ways that are likely to have far-reaching consequences for their future economic stability and well-being. The events of the past several months have also called attention to a number of existing systemic and structural barriers which have an immeasurable impact on graduating students at a critical point in their developing careers.

To begin with, the loss of the traditional convocation (graduation) ceremony is a hardship unlikely to provoke much public sympathy, yet it is deeply injurious to students and their families. Post-secondary education is an arc of experience, beginning with the expectancy during the application phase and culminating in the formal conferral of the degree during convocation. For many students, including those who are among the first in their family to obtain a post-secondary education, the loss of this ritual represents a lack of closure for which an online ceremony, however carefully planned, is a poor substitute. For Indigenous students and families in particular, the ceremonial conferral of degrees may represent an opportunity for healing and closure on a number of levels and across generations of the family's collective engagement with colonial structures of assimilation. The current situation offers an opportunity to ask whether online ceremonies are a sufficiently meaningful marker of graduation, and to consider how future ceremonies might better honour the particular experiences of 2020 graduates.

Graduating students face limited job prospects for the foreseeable future. With many potential employers operating with diminished resources, new graduates are left with the overwhelming burden of obtaining employment to meet their basic needs - a dilemma which creates pressure to accept positions or wages which undervalue their knowledge and experience. The closure of "non-essential businesses"7

\footnotetext{
7 The term non-essential businesses has come into use during this pandemic to refer to the recreational sector, such as restaurants, fitness studios, cinemas, concert halls, theatres and other event venues. Unlike supermarkets, pharmacies, banks etc. they are classified as not strictly necessary to keep daily life going
} 
across the country presents another challenge for those whose financial circumstances necessitate casual or part-time employment during their studies (Watts et al. 2020). If a student is able to obtain employment, start dates for in-person positions may be significantly delayed and others may be conducted remotely. For students engaged in the field of Indigenous health, where much work depends on partnerships created in-person and on the land, opportunities may be significantly limited until physical distancing is no longer a necessity. As with the online learning initiatives being undertaken by educational institutions, remote working requires resources that may not be financially attainable for newly graduated students. Acquiring the necessary technology, network connection, or even space to maintain a productive and enriching work environment are just some of several potential barriers an individual may face. As loans quietly accrue interest amidst disruption and uncertainty, a growing number of students find themselves more deeply constrained by the very systemic and structural inequities which they study and endeavour to dismantle.

The abrupt disruption of supportive social networks and the transition of all extra-familial social interactions to online formats also present challenges for many newly graduated students. At a time when students are expected to develop new relationships with peers and within the broader community, the constraints of physical distancing mean that these relationships can be significantly stilted. The act of making connections with more advanced students or scholar mentors can become very daunting over the internet, where every e-mail must be carefully constructed and each response interpreted without the non-verbal context of in-person interaction. Creating these meaningful networks is particularly crucial in the small but expanding field of Indigenous health research. Meanwhile, maintaining relationships with existing support networks can present its own set of challenges. With many individuals spending more time in front of a screen, fatigue and the desire for disconnection from the World Wide Web can turn friendly check-ins into a draining online exercise. Finding comfort in connection with friends, peers and a wider social network requires the difficult yet rewarding process of ongoing, honest communication.

For first-generation university graduates, losing the opportunity to celebrate a milestone with family and friends is an unfortunate consequence of our unprecedented COVID-19 reality. However, for members of the first graduating cohort of the University of Toronto's Indigenous Health programme, the sadness and unease weigh heavier as a result of the community and land-based advocacy rendered unactionable due to the pandemic. There is a strong sense of personal responsibility to act upon the teachings and experiences gained over the course of a graduate education in Indigenous health, and to continue to support the Indigenous community members and organisations who have contributed to this learning. The relationships developed with staff and clients at several Indigenous-led community organisations over the course of the past year and a half were largely a result of volunteering with these organisations on a regular basis. These face-to-face interactions allow one to

Footnote 7 (continued)

during periods of lockdown where the top priority is to reduce personal contact among crowds so as to bring down infection figures, 
gain some of the first-hand knowledge and experience necessary to begin to understand the needs of the community our partners serve. This experience, critical for any researcher planning to collaborate with Indigenous communities, and particularly for those at the early stages of their journey, is no longer accessible to current students and graduates, and this is not likely to change for some time.

COVID-19 has compelled emerging Indigenous health researchers to find new ways to maintain meaningful and reciprocal relationships with community partners. One option might be to return to land-based practices by supporting a community garden initiative which serves as a gathering place for community members while maintaining physical distance; another might be to offer COVID-19-related grantwriting support. Thus, there are some avenues still available for continued relationship building. While COVID-19 has put a spotlight on the glaring inequities facing Indigenous communities, including a lack of clean water, precarious housing (Thompson et al. 2020) and food insecurity (Levi and Robin 2020), it also highlights the continued resilience of these communities in a global pandemic. Many community organisations have developed and implemented innovative service provision methods that should serve as a guide for those attempting to adapt to our new research reality.

In Indigenous health research, there are few relationships more important than those which exist with Indigenous communities and community members themselves. Regular in-person meetings have had to transition into virtual meetings or phone calls. At most times, but especially in a global pandemic, community leaders are required at the front line of service provision to meet the changing needs of their communities, which limits their availability for research-related tasks. Hearing about the challenges many of our partners are facing has caused me to re-evaluate my own goals and intentions as an Indigenous health research trainee and to question the value of the work we are doing for the community. How do we remain engaged in partnerships at a time when we cannot physically support their work? What must we achieve in the context of Indigenous health research that will directly benefit communities, particularly in times of immediate need? Engaging in research co-creation means that the answers to these questions should come from meaningful dialogue and collaboration with our Indigenous community partners. By prioritising the voices of the community, we are able to devote our time to actions which are more likely to have a lasting and direct benefit for the communities involved.

\section{Perspectives from Angela Mashford-Pringle, an early-career scholar}

COVID-19 has highlighted many of the structural inequities within society, several of which are reflected in higher education. Scholars who engage with Indigenous communities through their research and teaching have a heightened awareness of these inequities, as they colour every aspect of their engagements.

Indigenous populations face multiple levels of inequity in accessing public health information and services. This is a consequence of arrangements for health service governance and funding that stem from principles in the Indian Act. The result has been a response to the global pandemic that leaves the burden of care for Indigenous 
communities, particularly those in remote and northern regions of Canada, up to Indigenous organisations and communities themselves. Many jurisdictions have responded by closing their borders. A few (such as Nunavut) ${ }^{8}$ have found safety and cultural resilience through on-the-land programmes that encourage well-equipped families to seek isolation through harvest and time in camps.

From a research perspective, the closure of community borders is both a wholly justified protective measure enacted on the part of First Nations, Métis and Inuit communities for the preservation of life and well-being, and a considerable impediment to research engagement for the foreseeable future. Emerging and earlycareer scholars whose work is centred in these communities, and whose participatory approach requires community direction and engagement, must set aside their research goals for the time being and do what they can to support research partners in their efforts to obtain essential supplies and protective equipment while they struggle with the closure of community borders. Similarly, those scholars working with off-reserve and urban Indigenous communities must minimise non-COVID research engagement in the interests of limiting potentially infectious exposure through in-person contact.

We are not suggesting that concern for research interlocutors is unique to Indigenous scholars. However, the particular inequities faced by Indigenous communities in Canada mean that investigators whose research involves deep engagement with these communities are particularly affected by this crisis. As well as putting up with practical impediments to their scholarly progress such as research delays and cancellations, these researchers must also come to terms with the knowledge that Indigenous people will bear a disproportionate burden of COVID-related disease and death, and that this burden is preventable.

The very mode of Indigenous scholarly engagement, which rests so heavily on face-to-face interaction, is hindered, perhaps rendered impossible, by the shift to online communication. Virtual meetings can be tricky as technology fails, which can disrupt discussion and leave important information unshared. For many communities, poor bandwidth means that online engagement is all but impossible, the only alternative being conversations by phone. Under these circumstances it is challenging to exchange information, share ideas and engage in nuanced interaction on subjects that are often difficult or trauma-informed. Even established researchers struggle to maintain existing relationships, let alone develop new ones, with a quality of trust sufficient to facilitate meaningful research engagement.

In this context, early-career scholars are struggling to maintain the levels of productivity required by their academic institutions for review and promotion. Before COVID, as an Indigenous researcher, it was possible to work with Elders, Knowledge Keepers and Indigenous organisations to build a relationship informed by

\footnotetext{
${ }^{8}$ Nunavut is a large, sparsely populated territory in the north of Canada which includes many islands and remote villages. But, just as we are finalising this article, news has come in that unfortunately, the pandemic has found its way here, too. The first case of COVID-19 among Nunavut's Inuit population was confirmed on 6 November 2020 (Frizzell 2020).
} 
Ownership, Control, Access \& Possession (OCAP $\left.{ }^{\mathrm{TM}}\right)^{9}$ created by and for research with Indigenous peoples. Relationship building is a central component to any research or policy programme. This has been rendered difficult as Indigenous communities rightly turn their attention to dealing with immediate health concerns that are not in alignment with academic, government, or other structural institutions' spheres of planning, preparation and work. Virtual working contravenes OCAPTM principles and will likely have a detrimental effect on future relationships and research currently in the conceptualisation or early planning stages.

It is understandable that the focus has now turned to working out how to provide meaningful and effective online courses. However, by their very nature these do not allow for land-based learning or interactions with Indigenous community members. This is a major problem. The shift to online teaching may not be problematic in all fields, but in fields such as Indigenous health, where understanding relationships between humans, animals, plants, water and land are essential to a holistic worldview ("all my relations"), ${ }^{10}$ the new format will mean yet more trauma and disconnection hindering the path to truth and reconciliation.

Conferences and travel have been halted during "The Great Pause", ${ }^{11}$ which will also have a negative impact on early-career researchers. All conferences in the spring and summer of 2020 were cancelled, eliminating important opportunities to share new and ongoing research. Conference presentations often lead to discussions with other more senior academics who can provide insight, connections or challenges that expand a project's knowledge base. Without these interactions, earlycareer researchers will not have access to the new contacts and networks that often lead to further research, guest lectures and potential examiners for graduate dissertations and theses.

\section{Perspectives from Tracey Galloway, an established scholar}

While scholars with well-established research careers share many of the aforementioned anxieties and workload issues, those concerns are at least buffered by the job security and academic freedom that accompanies tenured research and teaching positions. ${ }^{12}$ While our days may feel stressful - incredibly so given the extent of our networks and scholarly and administrative commitments - we may still be called upon to contribute additional efforts in support of our students, trainees and underemployed peers.

\footnotetext{
${ }^{9}$ OCAPTM is a registered trademark of the First Nations Information Governance Centre (FNIGC). For more information, visit https://fnigc.ca/ocap [accessed 8 November 2020].

10 Reference to "all my relations" extends beyond human relationships to include animals, plants, trees, waters, lands, etc. (Kainai Board of Education 2004).

11 In the context of the current pandemic, "the Great Pause", refers to how the world came to a sudden standstill in early 2020, especially in economic terms. Compared to the "Great Depression" of the 1920s in the context of an earlier pandemic, the Spanish Flu (1918-1920), the "Great Pause" perhaps expresses some hope of faster economic recovery.

12 A tenured researcher holds a permanent academic post.
} 
There are a number of ways in which we can support students at this difficult time. One concrete step would be to marshal available research funds in support of research assistants for tasks that can be completed in lieu of face-to-face data collection activities in Indigenous communities. Stipends, bursaries and work-study placements, however small, may alleviate some of the financial burden on students and recent graduates struggling with the cost of living. Our time, too, is a valuable commodity: journal clubs, ${ }^{13}$ reading groups and other social learning experiences, carried out through tele- or videoconferencing, can enhance "contact time" with trainees and ensure that people retain a sense of connectedness with peers and mentors. One potential solution involves adding an extra layer of weekly lab-group meetings and bi-weekly one-on-one chats with students to discuss their concerns navigating the "new normal". As student mentors, it is also important that we widen our circles of contacts to include students, those doing related, health-focused work, and faculty colleagues in order to deepen students' sense that there is a supportive scholarly community engaged in their work.

Teaching is another area that requires the support of established scholars. The shift to online learning is disproportionately burdening instructors with higher course loads (Harris 2020; Executive Committee of Tenure for the Common Good 2020). Through our departmental administrative roles, we can examine each course allocation and provide additional teaching assistant support for instructors moving multiple courses online. The burden of online instruction should not be underestimated. Even under normal conditions, there is considerable risk of burnout and exploitation among sessional and contract instructors. ${ }^{14}$ Wherever possible, tenureand teaching-stream ${ }^{15}$ faculty members can support other instructors through assiduous monitoring of the working conditions of these valued peers.

Time can be used in other ways to support the efforts of trainees and early-career scholars. For example, adjusting responses to peer review requests to include particular consideration of whether the given input might support the efforts of emerging academics. This involves allotting specific and significant time to peer review activities, for both journals and funding agencies. As the window of job prospects narrows, publications and grants are increasingly critical to the future job prospects of early-career scholars. Similarly, as conferences move online and opportunities for face-to-face networking decline, we must advocate within professional organisations to retain annual conference cycles and provide opportunities for scholars to share new research.

Established scholars can also advocate for their departments and divisions to proceed with new hires, to serve on search committees and to strengthen systems for countering conscious and unconscious forms of bias and oppression within hiring

\footnotetext{
13 A journal club is a regular, extracurricular meeting held amongst scholars to discuss published research.

14 A sessional instructor teaches course(s) on contract and is precariously employed (Rose 2020b). A contract instructor has a short fixed-term contract to carry out a number of courses during an allotted timeframe.

15 The main responsibility of a teaching-stream faculty member is to teach students rather than engaging in research.
} 
processes that replicate exclusion of Black, Indigenous, People of Colour and Queer scholars. Lack of face-to-face interviews and travel cannot mean that we postpone or de-prioritise these hires. There is an urgent need to broaden representation among tenure- and teaching-stream faculty members, both for the intellectual benefits that accompany diverse ways of knowing and also so that students (current and future) see their own identities and experiences reflected in their mentors and teachers.

Within our research communities, tenured faculty members may be called upon to advocate for policy justice and fairness in COVID-related funding and services. Many of us have published research in the areas of food security, child welfare, health service access, Elder care and Indigenous self-determination. We can continue to do this, highlighting issues relevant to present concerns. Many of us also have strong relationships with Indigenous scholars, leaders and community members living and working in urban, rural and remote contexts across Canada. These relationships can serve as pathways for the sharing of information in both directions. For example, when contacted by a member of the media wishing to discuss a topic relevant to Indigenous communities (these requests are now coming in frequently as the media struggle to keep pace with the impact of the pandemic on these communities), we can contact our networks to see if a Chief or other leader has information they wish to share. Keeping Indigenous voices and stories in the media reinforces the hard work Indigenous organisations are doing to advocate for a fair and equitable public health response.

This historical moment is one in which past injustices come to bear on the existential threat to communities presented by COVID-19. Through policy papers, "opeds" 16 and media articles, in classes and seminars, and through our efforts to stay in touch with communities and bear witness to their challenges and successes, we as scholars can write, teach and act in ways that advocate for social justice, inclusivity and fairness for First Peoples.

\section{Concluding thoughts: return to "normal"?}

As many wait for academic life to return to "normal", we ask: to what "normal" do we want to return?

At the heart of most Canadian post-secondary institutions are the dominant Western systems that continue to perpetuate colonial harms to Indigenous communities, students and faculty members. With that in mind, we wonder if the present substantial disruption might be seized as an opportunity to challenge the ways in which our institutions function. The shift to online learning may allow students more flexibility to learn in ways that work best for them. The move away from concrete classrooms and rigid schedules may also present an opportunity to privilege the Indigenous ways of learning that have been practised since time immemorial. Engaging in land-based learning - a pedagogy which centres traditional ecological

\footnotetext{
16 An op-ed is a newspaper item (often a personal comment, an opinion) featured opposite the editorial page.
} 
knowledge - and providing online learning options to remote Indigenous communities serve as two examples which could reduce community exposure to the virus. Preliminary research in the area appears to show that the spread of COVID-19 could be minimised in outdoor versus indoor settings (Nishiura et al. 2020; Qian et al. 2020), positioning land-based education as a viable alternative to indoor classroom settings. As with other social and political movements, we find ourselves at a unique juncture which carries great potential for positive change. Though faculty members are key advocates within their institutions, the responsibility does not lie solely in their hands. Students can play an active role in their education and have a powerful voice to advocate for their own learning needs.

This is not to say that this shift will be free of challenges. The task of re-imagining a new "normal" is daunting in itself. On behalf of those whose graduations are missed, or whose research is terminated indefinitely, we need to hold ourselves accountable to find alternative ways of acknowledging and compensating people for these losses. Those unfamiliar with online platforms have a great deal to learn in a very short time. Those who are more experienced must exercise patience as they assist their colleagues in rising to this challenge. This is crucial, because once we have adapted, these online formats could open up opportunities to explore collaborations that may not have been possible in traditional in-person formats. The options for guest lecturers, for example, are no longer limited to those within the same institution or city. We have the opportunity to expand the Indigenous voices that students hear to include those in rural, remote or distant locations.

To make all of this possible, we must acknowledge the central theme that runs true across our collective experience. The need for clear and open communication has never been greater. Communicating to students that something is unknown is far more informative than no communication at all. We must adapt our communication methods in ways that prioritise space for relationship-building. This extends beyond students and faculty members to the relationships we have built with our Indigenous partners. As communities find innovative ways to cope with their new realities, we must leverage our academic and other privileges to support them in every possible way. We must honour the importance of reciprocity in these relationships and use our specific skill sets to assist the community partners without whom our research would not be possible.

\section{References}

Allen, L., Hatala, A., Ijaz, S., Courchene, E. D., \& Bushie, E. B. (2020). Indigenous-led health care partnerships in Canada. Canadian Medical Association Journal, 192(9), E208-E216. https://doi. org/10.1503/cmaj.190728.

Almarzooq, Z. I., Lopes, M., \& Kochar, A. (2020). Virtual learning during the COVID-19 Pandemic: A disruptive technology in graduate medical education. Journal of the American College of Cardiology, 75(20), 2635-2638. https://doi.org/10.1016/j.jacc.2020.04.015.

Aragón, F. M., \& Kessler, A. S. (2020). Property rights on First Nations reserve land. Canadian Journal of Economics/Revue canadienne d'économique, 53(2), 460-495. https://doi.org/10.1111/caje.12434.

Attas, R. (2019). Strategies for settler decolonization: Decolonial pedagogies in a popular music analysis course. Canadian Journal of Higher Education, 49(1), 125-139. Retrieved 13 November 2020 from https://files.eric.ed.gov/fulltext/EJ1214715.pdf. 
Bowra, A., Mashford-Pringle, A., \& Poland, B. (2020). Indigenous learning on Turtle Island: A review of the land-based learning literature. Canadian Geographer [online first]. https://doi.org/10.1111/ cag. 12659.

Canadian Press (2020). Some Canadian universities say fall classes will be offered primarily online. $C B C$ News, 12 May [online news item]. Retrieved 20 June 2020 from https://cbc.ca/news/canada/covid -universities-online-1.5565810

Executive Committee of Tenure for the Common Good (2020). A very stable and secure position. Inside Higher Ed., 30 April [online article]. Retrieved 12 November 2020 from https://www.insidehigh ered.com/views/2020/04/30/covid-19-shows-how-precarious-positions-contingent-faculty-actuallyare-opinion.

Fortier, C. (2017). Unsettling methodologies/Decolonizing movements. Journal of Indigenous Social Development, 6(1), 20-36. Retrieved 13 November 2020 from https://journalhosting.ucalgary.ca/ index.php/jisd/article/view/58461.

Freemantle, J., Ring, I., Arambula Solomon, T. G., Gachupin, F. C., Smylie, J., Cutler, T. L., et al. (2015). Indigenous mortality (revealed): The invisible illuminated. American Journal of Public Health, 105(4), 644-652. https://doi.org/10.2105/AJPH.2014.301994.

Frizzell, S. (2020). Nunavut confirms 1st case of COVID-19. CBC News, 6 November [webnews]. Ottawa, ON: Canadian Broadcasting Corporation (CBC/Radio-Canada). Retrieved 8 November 2020 from https://www.cbc.ca/news/canada/north/nunavut-confirms-1st-covid-19-case-1.5792736.

Harris, S. (2020). Pandemic highlights precarious, unpaid work for post-secondary contract staff. Huffington Post, 31 August [online article]. Retrieved 12 November 2020 from https://www.huffingtonpost. ca/entry/contract-faculty-covid-19-risk_ca_5f32fa08c5b6fc009a5e7f2d?guccounter=1\&guce_refer rer=aHR0cHM6Ly93d3cuZ29vZ2x1LmNvbS8\&guce_referrer_sig=AQAAAIZW_2pw7hCSKr9 ieP1i6gBAKTwgJU40LSnZeqtf395goK80snk_SeI20f9eDaFRutIU2oLgapLQ1hvfD1OO82R w5nsmzVmteZ9C3Q-2KrD7cH4PZG441Dom-mZhVypzX7p70k048vRGyoGaqDUw45YWvVF8 TGWuuXttcqO_p0AC.

Humphreys, A. (2020). What might our lives look like when Canada is in the full grip of COVID-19? National Post, 14 March [online article]. Retrieved 20 June 2020 from https://nationalpost.com/ news/may-soon-be-completely-out-of-control-covid-19s-dire-possibilities-could-dramatically-chang e-canada.

Kainai Board of Education. (2004). All my relations. In Kainai Board of Education, Aboriginal Perspectives (pp. 71-80). Aboriginal Studies 10. Toronto, ON: Nelson Education. Excerpt retrieved 8 November 2020 from http://www.learnalberta.ca/content/aswt/well_being/documents/all_my_relat ions.pdf.

Lee, J. (2020). Mental health effects of school closures during COVID-19. Lancet Child \& Adolescent Health, 4(6), 421. https://doi.org/10.1016/S2352-4642(20)30109-7.

Levi, E., \& Robin, T. (2020). COVID-19 did not cause food insecurity in Indigenous communities but it will make it worse. Yellowhead Institute website, 29 April [online article]. Toronto, ON: Yellowhead Institute. Retrieved 20 June 2020 from https://yellowheadinstitute.org/2020/04/29/covid19-foodinsecurity/.

Nic Dhonncha, E., \& Murphy, M. (2020). Learning new ways of teaching and assessment: The impact of COVID-19 on undergraduate dermatology education. Clinical and Experimental Dermatology [online first, 3 July]. https://doi.org/10.1111/ced.14364.

Nicola, M., Alsafi, Z., Sohrabi, C., Kerwan, A., Al-Jabir, A., Iosifidis, C., et al. (2020). The socio-economic implications of the coronavirus pandemic (COVID-19): A review. International Journal of Surgery, 78, 185-193. https://doi.org/10.1016/j.ijsu.2020.04.018.

Nishiura, H., Oshitani, H., Kobayashi, T., Saito, T., Sunagawa, T., Matsui, T., Wakita, T., \& Suzuki, M. (2020). Closed environments facilitate secondary transmission of coronavirus disease 2019 (COVID19). Laurel Hollow, NY: medRxiv preprint server for health sciences. This article is a preprint and has not been peer-reviewed. It reports new medical research that has yet to be evaluated and so should not be used to guide clinical practice. https://doi.org/10.1101/2020.02.28.20029272v2.

PC (Parliament of Canada) (1985 [1876]). Indian Act: An Act respecting Indians. Act current to 2020-1021 and last amended on 2019-08-15. Revised Statutes of Canada (RSC). Ottawa, ON: Parliament of Canada. Retrieved 6 November 2020 from https://laws-lois.justice.gc.ca/eng/acts/i-5/fulltext.html.

Qian, H., Miao, T., LIU, L., Zheng, X., Luo, D., \& Li, Y. (2020). Indoor transmission of SARS-CoV-2. Laurel Hollow, NY: medRxiv preprint server for health sciences. This article is a preprint and has not been peer-reviewed. It reports new medical research that has yet to be evaluated and so should not be used to guide clinical practice. https://doi.org/10.1101/2020.04.04.20053058v1. 
Reading, C., \& Wien, F. (2009). Health inequalities and social determinants of Aboriginal peoples' health. Prince George, BC: National Collaborating Centre for Aboriginal Health (NCCAH). Retrieved 20 June 2020 from https://www.nccah-ccnsa.ca/495/Health_inequalities_and_the_socia 1_determinants_of_Aboriginal_peoples_health_nccah?id=46.

Richmond, C.A.M., \& Cook, C. (2016). Creating conditions for Canadian aboriginal health equity: The promise of healthy public policy. Public Health Reviews, 37, Art. 2 [online]. https://doi.org/10.1186/ s40985-016-0016-5.

Rose, S. (2020a). Medical student education in the time of COVID-19. Journal of the American Medical Association, 323(21), 2131-2131. https://doi.org/10.1001/jama.2020.5227.

Rose, D. (2020b). A snapshot of precarious academic work in Canada. New Proposals: Journal of Marxism and Interdisciplinary Inquiry, 11(1), 7-17. Retrieved 13 November 2020 from https://ojs.libra ry.ubc.ca/index.php/newproposals/article/view/192381/189998.

Sahu, P. (2020). Closure of universities due to coronavirus disease 2019 (COVID-19): Impact on education and mental health of students and academic staff. Cureus, 12(4), e7541-e7541. https://doi. org/10.7759/cureus.7541.

Smylie, J., \& Firestone, M. (2015). Back to the basics: Identifying and addressing underlying challenges in achieving high quality and relevant health statistics for Indigenous populations in Canada. Statistical Journal of the IAOS [International Association for Official Statistics], 31(1), 67-87. https:// doi.org/10.3233/SJI-150864.

Thompson, S., Bonnycastle, M., \& Hill, S. (2020). COVID-19, First Nations and poor housing: "Wash hands frequently" and "self-isolate" akin to "let them eat cake" in First Nations with overcrowded homes lacking piped water. Winnipeg, MB: Canadian Centre for Policy Alternatives. Retrieved 20 June 2020 from https://www.policyalternatives.ca/sites/default/files/uploads/publications/Manit oba\%20Office/2020/05/COVID\%20FN\%20Poor\%20Housing.pdf.

Viner, R. M., Russell, S. J., Croker, H., Packer, J., Ward, J., Stansfield, C., et al. (2020). School closure and management practices during coronavirus outbreaks including COVID-19: A rapid systematic review. Lancet Child \& Adolescent Health, 4(5), 397-404. https://doi.org/10.1016/S2352 $-4642(20) 30095-X$.

Watts, M., Ritchie, L. E., Brown, J. R., Fekete, M., Ranger, J., Newell, S., Putyra, M., Longo, M., Sullivan, P., Olexiuk, P., \& Wetter, C. Provincial governments restrict business operations in the fight against COVID-19. Osler, 24 Mar 2020 [online article]. Retrieved 12 November 2020 from https:// www.osler.com/en/resources/regulations/2020/provincial-governments-restrict-business-operations -in-the-fight-against-covid-19.

Wildcat, M., McDonald, M., Irlbacher-Fox, S., \& Coulthard, G. (2014). Learning from the land: Indigenous land based pedagogy and decolonization. Decolonization: Indigeneity, Education \& Society, 3(3) [online article]. Retrieved 12 Nov 2020 from https://jps.library.utoronto.ca/index.php/des/artic le/view/22248.

Publisher's Note Springer Nature remains neutral with regard to jurisdictional claims in published maps and institutional affiliations.

Tracey Galloway is a settler scholar of Indigenous health and an Assistant Professor in the Department of Anthropology, University of Toronto Mississauga.

Andrea Bowra is a PhD Student from white settler ancestry in Social and Behavioural Health Sciences at the Dalla Lana School of Public Health, University of Toronto.

Tenzin Butsang is a Tibetan PhD student in the Social and Behavioural Health Sciences at the Dalla Lana School of Public Health, University of Toronto.

Angela Mashford-Pringle is an Algonquin Assistant Professor and Associate Director at the Waakebiness-Bryce Institute for Indigenous Health, Dalla Lana School of Public Health, University of Toronto. 


\section{Affiliations}

Tracey Galloway ${ }^{1}$. Andrea Bowra ${ }^{2}$. Tenzin Butsang ${ }^{2}$. Angela Mashford-Pringle ${ }^{2}$ (D)

Tracey Galloway

tracey.galloway@utoronto.ca

Andrea Bowra

andrea.bowra@mail.utoronto.ca

Tenzin Butsang

tenzin.butsang@mail.utoronto.ca

1 Department of Anthropology, University of Toronto Mississauga, Mississauga, ON, Canada

2 Waakebiness-Bryce Institute for Indigenous Health, Dalla Lana School of Public Health, University of Toronto, Toronto, ON, Canada 